\title{
STUDY ON CHANGES OF SPERM HEAD MORPHOMETRY AND DNA INTEGRITY OF FREEZE-DRIED BOVINE SPERMATOZOA
}

\author{
S. Said, F. Afiati and T. Maulana \\ Research Centre for Biotechnology, Indonesian Institute of Sciences, \\ Jl. Raya Bogor Km. 46 Cibinong 16911-Indonesia \\ Corresponding E-mail: syahruddinsaid01@gmail.com \\ Received June 09, 2015; Accepted August 13, 2015
}

\begin{abstract}
ABSTRAK
Penelitian ini bertujuan menganalisis perubahan ukuran kepala dan integritas DNA spermatozoa sapi kering beku. Sperma kering beku disimpan pada temperature $4^{\circ} \mathrm{C}$ selama 2 tahun. Ukuran kepala sperma ditentukan dengan menggunakan Computer-assisted sperm analysis (CASA), sedangkan integritas DNA dianalisis pewarnaan acridine orange. Preparat ulas spermatozoa dibuat dan difiksasi dengan acetic alcoholdandiwarnai dengan acridine orange. Setelah diwarnai, setiap slide diamati dibawah mikroskop fluoresens pembesaran 400X dengan axio vision (Zeiss Company, Germany). Hasil penelitian menunjukkan bahwa ukuran kepala sperma membesar signifikan $(\mathrm{P}<0,05)$ setelah dikeringbekukan, sebaliknya kepala sperma mengalami pengecilan ukuran secara signifikan $(\mathrm{P}<0,05)$ setelah diinkubasi selama 3 dan 6 jam. Integritas DNA spermatozoa kering beku berbeda nyata $(\mathrm{P}<0,05)$ menurun setelah inkubasi selama 6 jam. Dapat disimpulkan bahwa (1) kepala spermatozoa mengalami pembesaran setalah melalui proses pengeringbekuan, sebaliknya mengalami pengecilan setelah proses inkubasi, (2) integritas DNA spermatozoa kering beku tetap utuh selama inkubasi 3 jam dan penurunan integritas DNA terjadi setelah inkubasi selama 6 jam.
\end{abstract}

Kata kunci : ukuran bentuk, integritas DNA, spermatozoa kering-beku, sapi, inkubasi

\begin{abstract}
Changes of sperm heads morphometric and DNA integrity of freeze-dried bovine spermatozoa were investigated. Freeze-dried spermatozoa had stored in the refrigerator at $4^{\circ} \mathrm{C}$ for 2 years. Computerassisted sperm analysis (CASA) was used in this study to identify sperm head morphometry, while for DNA integrity analysis using acridine orange staining. Samples were smeared on glass slides, fixed for 2 $\mathrm{h}$ in acetic alcohol and stained with acridine orange solution. After staining, each slide was examined at x400 magnification in a fluorescence microscope with axio vision (Zeiss Company, Germany). Proportion of fluorescence red and green emissions of the sperm head were examined and scored. These results indicated that sperm head had enlarged significantly $(\mathrm{P}<0.05)$ after freeze-drying process. However, freeze-dried sperm heads morphometry significantly $(\mathrm{P}<0.05)$ decrease after incubation for 3 and 6 hours. Changes of DNA integrity of freeze-dried spermatozoa significantly $(\mathrm{P}<0.05)$ decrease after incubation for 6 hours. In the present study concluded that (1) freeze-drying spermatozoa caused sperm head morphometric enlarged, whereas incubation time caused sperm heads decreased, (2) DNA integrity of freeze-dried sperm head is still intact during incubation 3 hours, and decreased DNA integrity occur in incubation for 6 hours.
\end{abstract}

Keywords :morphometry, DNA integrity, freeze-dried spermatozoa, bovine, incubation 


\section{INTRODUCTION}

Freeze-drying has become an alternative method to preserve mammalian spermatozoa, instead of cryopreservation (Wakayama et al., 1998; Kusakabe et al., 2001; Kaneko et al., 2003). In the freeze-drying process, spermatozoa were exposed in liquid nitrogen at a temperature of minus $196^{\circ} \mathrm{C}$ to obtain frozen spermatozoa. Frozen spermatozoa were then sublimed to vaporize the frozen water phase that will eventually be obtained preparations of dry spermatozoa. Both of these processes could alter the plasma membrane, acrosome status and morphology of spermatozoa (Saili et al., 2006) may even destabilize the DNA contained in the sperm chromatin structure. The evaluation of DNA status is not included in the standard semen analysis, but the frequency of spermatozoa containing fragmented DNA may be an important parameter of semen quality and a useful index of fertility potential.Virro et al. (2004) reported that spermatozoa with severe DNA damage remain functionally intact, with normal fertilizing ability, but a high incidence of DNA fragmentation results in a significant decrease in pregnancy rates

Although freeze-drying of sperm is a useful technique, especially for animal conservation programs, it cause more damages than the conservation procedures. When mammalian spermatozoa are freeze-dried, they lose motility and therefore, they are unable to fertilize oocytes, both in vitro and in vivo (Liu et al., 2004). Nevertheless, if an intact nucleus is present in the sperm, they can be used to fertilize oocytes through intracytoplasmic sperm injection (ICSI) and are able to produce live offspring, as has been demonstrated in mice and rabbits (Kwon et al., 2004). Sperm quality and fertilization rate, embryo cleavage and pregnancy after IVF or ICSI is strongly associated with the concentration of SS-DNA in sperm (Evenson et al, 1999). VirantKlun et al. (2002) report that increased level of sperm single-stranded DNA in infertile men results in fewer embryos suitable for transfer and cryopreservation. The integrity of the sperm nucleus is also determined by the content of SSDNA in sperm.

Preservation of the sperm cells is obtained by water removal due to ice sublimation, under a strong vacuum. However, freeze-dried sperm could result in damage tospermatozoa. In cattle and other mammalian have been widely studied the effects of cryopreservation on sperm function and fertility. The reduction of sperm quality in cryopreserved semen and reveals that temperatures under $5^{\circ} \mathrm{C}$ seem to be a major factor in explaining the failure of sperm to survive the freezing-thawing process (Sancho et al., 2007). Various sperm organelles have been known to be affected due to the detrimental effects of cryopreservation. Induction of premature acrosomal reaction, altered mitochondrial function, reduction of motility and failure of chromatin decondensation, all of which influence the viability and fertility of the sperm cells have been reported by different authors (Chaveiro et al., 2006; Cooter et al., 2005; Watson, 2000; Wongtawan et al., 2006).

Januskauskas et al. (2003) showed that sperm chromatine structure altered during cryopreservation, which may be associated with subtle membrane changes. This alteration appears to be responsible for a reduction in sperm head surface area (Royere et al., 1988), which may result from overcondensation of the sperm nuclear chromatin. The resulting alterations in chromatin appears to be associated with reduced sperm fertility in bulls (Januskauskas et al., 2003).

Cryopreservation of bovine spermatozoa has been demonstrated to significantly decrease the length, width and surface area of the sperm head (Gravance et al., 2009), but there is no information about the change in the size of the sperm head results of freeze dried spermatozoa.

The damages of sperm nucleus can be induced by mechanical stress throughout the freeze-drying procedure or by oxidative stress, which occurs after thawing or rehydration, during the holding period before ICSI (Kusakabe et al., 2001). Its means, all steps of the sperm freezedrying procedures to its use to fertilize oocytes, can affect the status of the sperm nucleus.

Because the sperm head consists almost entirely of DNA, subtle differences in sperm head morphometry might be related to DNA content and organization, as demonstrated in dogs (Lange et al., 2010) and humans (Mangiarini et al., 2013). Therefore, in the present study was investigated the changes of sperm heads morphometric and sperm DNA integrity of freezedried bovine spermatozoa kept for 2 years at $4^{\circ} \mathrm{C}$.

\section{MATERIALS AND METHODS}

\section{Animals}

Semen samples were obtained from 4 years old Simmental Bulls. The bulls were reared in the 
Research Center for Biotechnology - LIPI's farm. Semen was collected by using artificial vagina during mid-morning after an extended period of routine collection every week. Semen quality consist of volume, concentration, motility and abnormality of the sperm were evaluated prior to freezing.

\section{Frozen-Thawed Spermatozoa}

Evaluated sperm were diluted with medium containing Tris (hydroxymethyl) aminomethan $(3.09 \%)$, citrate acid $(1.73 \%)$, fructose $(1.27 \%)$, and added $20 \%(\mathrm{v} / \mathrm{v})$ egg yolk and antibiotic $1 \%$ $(\mathrm{v} / \mathrm{v})$. Diluted sperm were filled in $0.25 \mathrm{~mL}$ straw and sealed using filling and sealing machine, and then equilibrated for 2 hour in cool top. Furthermore, pre-freezing was done by placing straw $6 \mathrm{~cm}$ above of liquid nitrogen (LN2) for 10 min and straw were then drowned in LN2 and kept in LN2 container. The frozen semen sample were thawed by dipped into the water $37^{\circ} \mathrm{C}$ for 30 sec.

\section{Freeze-Drying and Rehydration Spermatozoa}

Sperm concentration was adjusted to $10 \mathrm{x}$ $10^{6}$ spermatozoa/100 $\mu \mathrm{L}$ freeze-drying solution. The freeze-drying medium was $10 \mathrm{mmol} / \mathrm{L}$ Tris$\mathrm{HCl}$ buffered supplemented with $50 \mathrm{mmol} / \mathrm{L}$ of each of $\mathrm{NaCl}$ and EGTA [ethylene glycol-bis( $\beta$ aminoethyl ether)-N,N,N',N'-tetra acetic acid], $\mathrm{pH}$ was adjusted to 7.2. The sperm suspension were plunged into LN2 for $20 \mathrm{sec}$ and then attached to a freeze-drying apparatus (Freeze-dry system, Eyela, Tokyo-rika Co., Japan), previously stabilized at $-40^{\circ} \mathrm{C}$ and $350 \times 10^{-3}$ Mbar pressure. After more than $4 \mathrm{~h}$ under lyophilization, vials containing the samples were completely and stored in the refrigerator $\left(4^{\circ} \mathrm{C}\right)$ for 2 years. The freeze-dried sample were rehydrated by adding $100 \mu \mathrm{L}$ of ultra pure water at room temperature.

\section{Intact Membrane Plasma (IMP) Spermatozoa}

IMP of spermatozoa was determined by calculation of the percentage of spermatozoa having intact plasma membrane by osmotic resistance test method (Revell and Mrode, 1994). Hypo-osmotic solution composition comprising : $0.9 \mathrm{~g}$ of fructose, $0: 49 \mathrm{~g}$ of sodium citrate were dissolved with aquabidestilata up to a volume of $100 \mathrm{ml}$. A total of $200 \mu \mathrm{L}$ of hypo-osmotic solution was added to $20 \mu \mathrm{L}$ semen, mixed until homogeneous, then incubated at $37^{\circ} \mathrm{C}$ for 45 minutes. Semen samples were smeared on a glass object and evaluated with $400 \mathrm{X}$ magnification microscope to a minimum of 200 spermatozoa. Spermatozoa having intact plasma membrane was characterized by circular tail or ballooned, while damaged marked with a straight tail.

\section{Morphometry Analysis}

Sperm samples were smeared on glass slide, air-dried prior to fixation for $2 \mathrm{~h}$ in acetic alcohol (Said et al., 2003). Slides were sealed prior to computer assisted sperm analysis (CASA). Sperm head measurements were analyzed at $400 \mathrm{X}$ magnification using Axio Vision (Zeiss Company, Germany).

The morphometric dimentions of length (L), width (W), and area (A) of a minimum of 200 properly detected and measured sperm heads were analyzed from each slide by CASA. The mean sperm head and standard deviation measurements were calculated by the CASA instrument and recorded.

\section{Evaluation of DNA Integrity with the Acridine Orange}

In this study, DNA integrity of freeze-dried spermatozoa was evaluated by using acridine orange staining technique.Samples of spermatozoa were smeared on glass slides, airdried, fixed for $2 \mathrm{~h}$ in acetic alcohol (1 part glacial acetic acid plus 3 parts $100 \%$ methanol) and airdried again. After fixation, sperm samples were stained with acridine orange solution (at 1000x dilution with GL-PBS) overnight (Said et al., 2003). After staining, each slide was washed with distilled water and sealed with synthetic resin to prevent it from drying. Slides were examined with fluorescence microscope (Axiophot Zeiss; $490 / 530 \mathrm{~nm}$ excitation/barrier filter). Two hundred cells were analyzed in each treatment slide. Sperm with normal DNA content present a green fluorescence, whereas sperm with abnormal DNA content emit fluorescence in a spectrum varying from yellow-green to red. The percentage of sperm with intact chromatin was calculated by dividing the number of green-stained sperm by the total number of sperm and multiplying the result by 200 .

\section{Experimental Design}

This study was designed to know the changes of sperm heads morphometric and sperm DNA integrity of frozen-thawed and freeze-dried bovine spermatozoa kept for 2 years at $4^{\circ} \mathrm{C}$. Parameters observed in this study was sperm head morphometry dimensions of length (L), width 
(W), and area (A) analyzed by CASA, and DNA integrity using a staining acridine orange test.

Acridine orange intercalates into doublestranded DNA as a monomer, whereas it binds to single-stranded DNA as an aggregate. Upon excitation at $470-490 \mathrm{~nm}$, the monomeric acridine orange bound to double-stranded DNA fluoresces green with an emission maximum at $530 \mathrm{~nm}$, and the aggregated acridine orange on single-stranded DNA fluoresces red with an emission at about 640 nm (Peacocke, 1973).

\section{Statistical Analysis}

Data regarding to semen parameters recorded were analyzed by analysis of variance (ANOVA). The difference among means was tested by Duncan Multiple Range Test and would have been considered different at an alpha level of $0.05(\mathrm{P} \leq 0.05)$.

\section{RESULTS AND DISCUSSIONS}

\section{Frozen-Thawed dan Freeze-Dried sperm head morphometric}

Summary of morphometric of frozen-thawed and freeze-dried sperm heads are presented in Table 1. Freeze-dried sperm heads morphometric (length, width and area) were not significantly different $\quad(\mathrm{P}>0.05) \quad$ with frozen-thawed spermatozoa, however,freeze-dried sperm head morphometric were significantly increased $(\mathrm{P}<0.05)$ than fresh sperm heads as control. These results indicated that sperm head had enlarged after freeze-drying process. This results different from the previous founding in the frozen-thawed spermatozoa demonstrated to significantly decrease the length, width and surface area of the sperm head (Gravance et al., 2009). This difference is due to differences of the intact plasma membrane spermatozoa. In was in this study that intact plasma membrane of freeze-dried spermatozoa $(16.81 \pm 9.75)$ had significantly $(\mathrm{P}<0.05)$ lower than fresh spermatozoa $(77.25 \pm$ 3.52). This condition indicated that plasma membrane of freeze-dried spermatozoa more damaged resulting in a medium more easily enter when rehydrated, and sperm have an enlarged size. In addition, cooling process of freeze-dried sperm is extremely rapid caused large intracellular ice crystals form.

During the process of freezing, several biophysical changes are evident within the semen sample. As the temperature drops to below freezing, the sample undergoes supercooling. As the temperature drops further beyond supercooling, extracellular ice crystals begin to form from the water within the surrounding medium. This ice formation increases the concentration of solutes, such as sugars, salts and proteins. In response to this newly developed osmotic pressure gradient and the fact that water within the spermatozoon is slower to form ice crystals than the water in the surrounding medium, water passes out of the spermatozoa, particularly from the spermatozoon head, across the semi-permeable plasma membrane. Consequently, the spermatozoon becomes increasingly dehydrated (Andrabi, 2007). The rate of efflux of water from the spermatozoa also depends upon the speed of temperature drop. The slower the drop, the greater would be the time needed for the efflux of water, and hence a much greater dehydration.

On the other hand, if the cooling rate is rapid, water has little time to move out of the spermatozoon and hence large intracellular ice crystals form, causing physical damage to cell membranes and other intracellular components. In the study using freeze-dried spermatozoa where the cooling process is very rapid, that way severe damage in the acrosome and membrane plasma. When the sperm were rehydrated apparently not

Table 1. Morphometric of Frozen-thawed and Freeze-dried Sperm Heads

\begin{tabular}{lccl}
\hline \multicolumn{1}{c}{ Sperm Heads } & \multicolumn{3}{c}{ Morphometric } \\
\cline { 2 - 4 } & Length $(\mu \mathrm{m})$ & Width $(\mu \mathrm{m})$ & Area $\left(\mu \mathrm{m}^{2}\right)$ \\
\hline Fresh Spermatozoa & $9.29 \pm 0.01^{\mathrm{a}}$ & $4.78 \pm 0.06^{\mathrm{a}}$ & $36.58 \pm 0.01^{\mathrm{a}}$ \\
Frozen-thawed Spermatozoa & $9.56 \pm 0.22^{\mathrm{ab}}$ & $5.02 \pm 0.12^{\mathrm{ab}}$ & $44.42 \pm 0.01^{\mathrm{ab}}$ \\
Freeze-dried Spermatozoa & $9.72 \pm 0.01^{\mathrm{b}}$ & $5.18 \pm 0.01^{\mathrm{b}}$ & $45.77 \pm 0.01^{\mathrm{b}}$ \\
\hline
\end{tabular}

${ }^{a, b}$ Mean \pm SD with different superskrip at the same column indicates significantly different $(\mathrm{P}<0.05)$. 
directly melted and water come out from the sperm head but need time.

Wakayama et al. (1998) showed that freezedried spermatozoa damaged in the acrosome and membrane plasma. Mammalian sperm are very sensitive to lower temperature. The freezing induces membrane alteration, which when thawed, causes changes in protein activity and subsequently altered permeability to water and solutes (Lemma, 2011).

\section{Effect of Incubation Time on Freeze-dried Sperm Head Morphometry}

Summary morphometry of freeze-dried sperm heads with different incubation times are presented in Table 2. Freeze-dried sperm heads morphometric decreased significantly $(\mathrm{P}<0.05)$ for incubation $3 \mathrm{~h}$ than control and no significantly different for incubation $6 \mathrm{~h}$.

Due to the relationship between sperm head morphometry and chromatine structure (Sailer et al., 1996), it would be logical to believe that morphometry changing and occuring during incubation would be associted with change in chromatine structure. The resulting alterations in chromatine appears to be associated with reduced sperm fertility in bulls (Januskauskas et al., 2003). Subtle differences in sperm head morphometry might be related to DNA content and organization, as demonstrated in dogs (Lange et al., 2010) and humans (Mangiarini et al., 2013).

It was found in the present study that freezedried sperm heads morphometry (length, width and area) significantly decreased after incubation for 3 and 6 hours. This finding indicated that chromatin structure of sperm nucleus had changed. When the freeze-dried sperm were rehydrated apparently the ice crystal in the sperm head not directly melted, but need time to melt. Clearly, reduction of sperm head morphometry is not caused byfreeze-drying process, but it was caused by incubation process.

Since the studies shown that fully dried spermatozoa have completely damaged plasma membranes (Liu, 2004), the earlier studies may have dealt with incompletely dehydrated sperm samples. The standart procedure of intracytoplasmic sperm injection (ICSI), isolation of sperm heads is usually performed prior to injections in order to increase the efficiency of the procedure. Consequently, the isolated sperm heads undergo an inevitable incubation in vitro. Long et al. (2013) reported that incubated sperm heads at $37^{\circ} \mathrm{C}$, a significant time dependent decrease in fertilization and blastocyst formation after ICSI.

\section{DNA Integrity of Freeze-dried Bovine Spermatozoa}

DNA integrity of freeze-dried bovine spermatozoa is presented in Table 3. When spermatozoa were stained with acridine orange after fixation with acetic alcohol, the DNA integrity of all fresh spermatozoa and incubation for $3 \mathrm{~h}$ and $6 \mathrm{~h}$ were remain intact of $500(100 \%$; Table 3, Figure 1). Only freeze-dried spermatozoa which cultured for $6 \mathrm{~h}$, their DNA integrity were decreased up to $14 \%$ (Table 3, Figure 2) and significantly different $(\mathrm{P}<0.05)$ than other treatment, indicated that DNA integrity of freezedried bovine spermatozoa kept for 2 years in the refrigerator at $4^{\circ} \mathrm{C}$, remain the integrity of their nucleus with incubation for $3 \mathrm{~h}$ treatment. The decreased DNA integrity occur in incubation for 6 hours.

The existence of chromatin in the cell nucleus determine the status of DNA tightly bound to the protamine which to function as a protector for nuclear DNA. Changes inchromatin will result in achange in the status of DNA, so that examination conditions can describe the status of chromatin DNA contained in the

Table 2. Freeze-dried Sperm Head Morphometry with Different Incubation Times

\begin{tabular}{lrrr}
\hline \multirow{2}{*}{ Morphometry } & \multicolumn{3}{c}{ Incubation Times $(\mathrm{h})$} \\
\cline { 2 - 4 } & \multicolumn{1}{c}{0} & \multicolumn{1}{c}{3} \\
\hline Length $(\mu \mathrm{m})$ & $9.72 \pm 0.01^{\mathrm{a}}$ & $9.55 \pm 0.01^{\mathrm{b}}$ & $9.53 \pm 0.01^{\mathrm{b}}$ \\
Width $(\mu \mathrm{m})$ & $5.18 \pm 0.01^{\mathrm{a}}$ & $5.07 \pm 0.01^{\mathrm{b}}$ & $5.03 \pm 0.01^{\mathrm{b}}$ \\
Area $\left(\mu \mathrm{m}^{2}\right)$ & $45.77 \pm 0.01^{\mathrm{a}}$ & $42.73 \pm 0.01^{\mathrm{b}}$ & $41.45 \pm 0.01^{\mathrm{b}}$ \\
\hline
\end{tabular}

${ }_{\mathrm{a}, \mathrm{b}} \mathrm{Mean} \pm \mathrm{SD}$ with different superskrip within columns is differ significantly $(\mathrm{P}<0.05)$. 
Table 3. DNA Integrity of Freeze-dried Bovine Spermatozoa using Acridine Orange Method

\begin{tabular}{|c|c|c|}
\hline \multirow{2}{*}{ Treatments } & \multicolumn{2}{|c|}{ DNA Integrity (\%) } \\
\hline & Intact & No intact \\
\hline Fresh Sperm 0H & $500(100.00)^{a}$ & $0(0.00)^{2}$ \\
\hline Fresh Sperm 3H & $500(100.00)^{\mathrm{a}}$ & $0(0.00)^{2}$ \\
\hline Fresh Sperm 6H & $500(100.00)^{\mathrm{a}}$ & $0(0.00)^{2}$ \\
\hline Freeze-dried Sperm $0 \mathrm{H}$ & $488(97.67)^{\mathrm{a}}$ & $12(2.33)^{a}$ \\
\hline Freeze-dried Sperm $3 \mathrm{H}$ & $499(99.83)^{\mathrm{a}}$ & $1(0.17)^{a}$ \\
\hline Freeze-dried Sperm $6 \mathrm{H}$ & $430(86.00)^{b}$ & $70(14.00)^{b}$ \\
\hline
\end{tabular}

$\mathrm{a}, \mathrm{b}=$ different superscripts in the same column indicated significantly different $(\mathrm{P}<0.05$

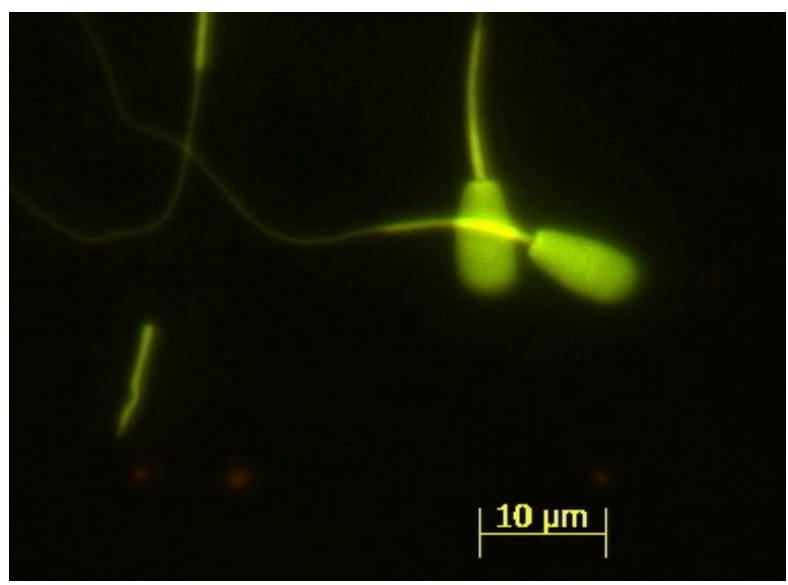

Figure 1. Changes the DNA Integrity of Bovine Fresh Spermatozoa. Double-stranded DNA Fluoresces Green

chromatin.

Freeze-drying is an alternative method for the preservation of sperm cells. However, it can cause irreversible injury to sperm structure, especially if suitable protection is not provided during the process and during storage. Considering these aspect, we evaluated how well the acridine orange (AO) test, detect injuries to DNA when bovine spermatozoa are lyophilized.

One of methods usually used was developed for detecting changes in the chromatin structure of DNA integrity, that was sperm chromatin structure assay (SCSA) (Chohanet al., 2006). The SCSA method utilizes the metachromatic properties of $\mathrm{AO}$. This stain fluoresces in the green band when intercalates into the intact double-stranded DNA helix, and in the red band when associated with single strand denaturated

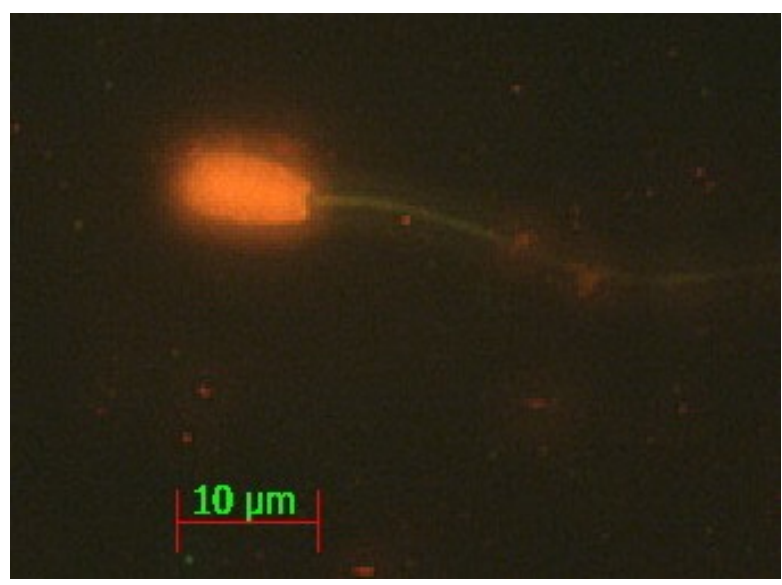

Figure 2. Changes of the DNA Integrity of Bovine Freeze-dried Spermatozoa. Single-stranded DNA Fluoresces Red

DNA and RNA. After denaturation of chromatin by decreased $\mathrm{pH}$, the spermatozoa with structurally abnormal chromatin fluorescence is detected in the red band (Bocheneket al., 2001).

It was demonstrated in the present study that the change of DNA stability of sperm heads against an acid treatment can be evaluated by using fluorescence microscopy. The proportion of acridine green fluorescence decreased to $86 \%$ when the spermatozoa were freeze-drying and incubated for $6 \mathrm{~h}$, means DNA integrity of the sperm decreased $14 \%$.

The ICSI has been applied to humans (Palermo et al., 1992), mice (Kimura and Yanagimachi, 1995) and rats (Hirabayashi et al., 2002; Said et al., 2003). Normal mouse offspring (Kusakabe et al., 2001) and bovine blastocyst development (Keskintepe et al., 2002) have been 
obtained from oocytes injected with freeze-dried spermatozoa, indicated that freeze-dried spermatozoa can be used for normal fertilization, development embryo and obtained offspring when injected into oocytes.

The present study showed that DNA integrity of sperm head was still intact during incubation 3 hours, although in that time morphometric of sperm head reduced. Therefore, it is advisable that ICSI should be implemented less than 3 hours of incubation.

\section{CONCLUSION}

Tfreeze-drying spermatozoa caused sperm head morphometric enlarged, whereas incubation time caused sperm heads decreased. DNA integrity of freeze-dried sperm head is still intact during incubation 3 hours, but in that time morphometric of sperm head reduced. It is recommends that implementation of intracytoplasmic sperm injection (ICSI) should be not more than 3 hours.

\section{ACKNOWLEDGEMENTS}

The authors would like to thank Research Center for Biotechnology, Indonesian Institute of Sciences for financial support contract No. SPDIPA-079.01.2.450083/2014.

\section{REFERENCES}

Andrabi, S. M. H. 2007. Fundamental principles of cryopreservation of Bos taurus and Bos indicus bull spermatozoa. Mini review. Int. J. Agr. Biol. 9:367-369

Bochenek, M., Z. Smorąg and J. Pilch. 2001. Sperm chromatin structure assay of bulls qualified for artificial insemination. Theriogenology.56: 557-567.

Chaverio, A., L. Machado, A. Frijters, B. Engel, and H. Woelders, 2006. Improvement of parameters of freezing protocol for bull sperm using two osmotic supports. Theriogenology. 65:1875-1890.

Chohan, K.R., J.T. Griffin, M. Lafromboise and C.J. De Jonge. 2006. Comparison of chromatin assays for DNA fragmentation evaluation in human sperm. J. Androl. 27:5359.

Cooter P. Z., H. A. Goolsby, and S. D. Prien. 2005. Preliminary evaluation of a unique freezing technology for bovine spermatozoa cryopreservation. Reprod. Dom. Anim. 40:98-99.

Evenson, D. P., L. K. Jost, D. Marshall, M. J. Zinaman, E. Clegg, K. Purvis, P. de Angelis and O. P. Claussen. 1999. Utility of the sperm chromatin structure assay as a diagnostic and prognostic tool in the human fertility clinic. Hum. Reprod. 14:1039-1049.

Gravance, C. G., M. E. Casey and P. J. Casey. 2009. Pre-freeze bull sperm head morphometry related to post-thaw fertility. Anim. Reprod. Sci. 114:81-88.

Hirabayashi, M., M. Kato, T. Aoto, A. Sekimoto, M. Ueda, I. Miyoshi, N. Kasai and S. Hochi. 2002. Offspring derived from intracytoplasmic injection of transgenic rat sperm. Transgenic Res. 11:221-228.

Januskauskas, A., A. Johannison and $H$. Rodriguez-Martinez. 2003. Subtle membrane changes in cryopreserved bull semen in relation with sperm viability, chromatin structure and field fertility. Theriogenology. 60: 743-758.

Kaneko, T., D.G. Whittingham, J. W. Overstreet and R. Yanagimachi. 2003. Tolerance of the mouse sperm nuclei to freeze-drying depends on their disulfide status. Biol. Reprod. 69:1859-1862.

Keskintepe, L., G. Pacholczyk, A. Machnicka, K. Norris, M. A. Curuk, I. Khan and B. G. Brackett. 2002. Bovine blastocyst development from oocytes injected with freeze-dried spermatozoa. Biol. Reprod. 67: 409-415.

Kimura, Y. and R. Yanagimachi. 1995. Intracytoplasmic sperm injection in the mouse. Biol. Reprod. 52:709-720.

Kusakabe, H., M. A. Szczygiel, D. G. Whittingham and R. Yanagimachi. 2001. Maintenance of genetic integrity in frozen and freeze-dried mouse spermatozoa. Appl. Biol. Sci. 98:13501-13506.

Kwon, I. K., K. E. Park and K. Niwa. 2004. Activation, pronuclear formation, and development in vitro of pig oocytes following intracytoplasmic injection of freeze-dried spermatozoa. Biol. Reprod. 71: 1430-1436.

Lange-Consiglio, A., N. Antonucci, S. Manes, B. Corradetti, F. Cremonesi and D. Bizzaro. 2010. Morphometric characteristics and chromatin integrity of spermatozoa in three Italian dog breeds. J. Small Anim. Pract. 51:624-627.

Lemma, A. 2011. Effect of cryopreservation on 
sperm quality and fertility, artificial insemination in farm animals. In Edition : Dr. Milad Manafi 191-216. In Tech Publishers.

Liu, J. L., H. Kusakabe, C. C. Chang and H. Suzuki.2004. Freeze-dried sperm fertilization leads to full-term development in rabbits. Biol. Reprod. 70: 1776-1781.

Long, H., S. S. Lu, Y. P. Kuang, Z. G. Yan, H.X. Liang, S. Yu, W. R. Chai, Z. Yan and Q. F. Lyu. 2013. Incubation of sperm heads impairs fertilization and early embryo development following intracytoplasmic sperm injection (ICSI) by decreasing oocyte activation in mice. Biotechnol. Lett. 35(11):1823-1829.

Mangiarini, A., A. Paffoni, L. Restelli, S. Ferrari, C. Guarneri, G. Ragni and E. Somigliana. 2013. Specific sperm defects are differentially correlated with DNA fragmentation in both normozoospermic and teratozoospermic subjects. Andrology. 1:838844.

Palermo, G., H.Joris, P. Devroey and A. C. Van Steirteghem. 1992. Pregnancies after intracytoplasmic injection of single spermatozoa into an oocyte. Lancet. 340:1718.

Peacocke, A.R. 1973. The interaction of acridine with nucleic acids. In: Acridines, ed. R.M. Acheson723-754. New York: Inter science Publishers.

Revell, S. G. and R. A. Mrode. 1994. An osmotic resistance test for bovine semen. Anim. Reprod. Sci. 36:77-86.

Royere, D., S. Hamamah, J. C. Nicolle, C. Barthelemy and J. Lansac. 1988. Freezing and thawing alter chromatine stability of ejaculated human spermatozoa: fluorescence acridine staining and Fuelgen-DNA cytophotometric studies. Gamete Res. 21: 5157.

Sailer, B.L., L. K. Jost and D. P. Evenson. 1996. Bull sperm head morphometry related to abnormal chromatinestrucyure and fertility. Cytometry 24: 167-173.
Said, S., M. S. Han and K. Niwa. 2003. Development of rat oocytes following intracytoplasmic injection of sperm heads isolated from testicular and epididymal spermatozoa. Theriogenology. 60(2):359-369.

Saili, T. 2006. Morfologi dan integritas DNA spermatozoa domba setelah diawetkan dengan metode pengeringbekuan. Disertasi. Sekolah Pascasarjana Institut Pertanian Bogor, Bogor.

Sancho, S., I. Casas, H. Ekwall, F. Saravia, H. Rodriguez-Martinez, J. E. Rodriguez-Gil, E. Flores, E. Pinart, M. Briz, N. Garcia-Gil, J. Bassols, A. Pruneda, E. Bussalleu, M. Yeste and S. Bonet. 2007. Effects of cryopreservation on semen quality and the expression of sperm membrane hexose transporters in the spermatozoa of Iberian pigs. Reprod. 134: 111-121.

Virant-Klun, I., T. Tomazevic, and H. MedenVrtovec. 2002. Sperm single-stranded DNA, detected by Acridine Orange Staining, reduces fertilization and quality of ICSIderived embryos. J. Assist. Reprod. Gen. 19(7):319-328.

Virro, M. R., K. L. Larson-Cook and D. P. Evenson. 2004. Sperm chromatin structure assay (SCSA) parameters are related to fertilization, blastocyst development, and ongoing pregnancy in in vitro fertilization and intracytoplasmic sperm injection cycles. Fertil. Steril. 81:1289-1295.

Wakayama, T., D. G. Whittingham and R. Yanagimachi. 1998. Production of normal offspring from mouse oocytes injected with spermatozoa cryopreserved with or without cryoprotection. J. Reprod. Fertil. 12:11-17.

Wongtawan, T., F. Saravia, M. Wallgren, I. Caballero and H. Rodriguez-Martinez, 2006. Fertility after deep intra-uterine artificial insemination of concentrated low-volume boar semen doses. Theriogenology. 65:773787 